mountains, some of them reaching to a height of 5000 fect, runs down the centre of the peninsula, and through this the large navigable river Kamchatka makes its way to the Pacific Ocean. The vallcy of this river is the most cultivated portion of the district. The hills are covered with forests of fir, larch, cedar, birch, \&c., and in these are found numerous wild animals, such as the fur sable, the otter, foxes of all colours, and the bear, which latter, on account of the great supply of food, attacks neither man nor the domestic animals. It is curious to note that the squirrel, which is universal in Siberia, is not found here at all. Swans, wild ducks, \&c., are found in great quantities in the lakes and marshes in the interior, and their eggs, as well as the birds themselves, are taken in great numbers by the people. The fish which throng the rivers in enormons numbers in the summer form the principal food of the natives. For the most part they are salmon (Salmo salar), and are dried and storcd up for the winter; but owing to the scarcity and dearness of salt the fish frequently become rotten, and the people suffer great privation. The rigour of winter is much softened by warm ocean currents, which create those thick continuous fogs that render the coast so dangerous to navigation. The total population of both sexes is put d w wn at only 6500 souls, but owing to the total absence of agriculture, and to the primitive methods adopted for preserving food for the winter, these are frequently in a state of semi-starvation. For all except bare food they have to look abroad-clothes, utensils, tea, tobacco, \&c., and all these they purchase by means of their fur sable, which is unequalled in any other part of the world. About 5000 of these skins are sold each year at 15 to 20 roubles cach. At the beginning of the present century, cattle were introduced from Yakutsk, and, owing to the excellent grass and water, would have thriven well, but on account of the lack of industry or energy on the part of the natives, it was found impossible to lay in sufficient stores of fodder in winter. The question whether agriculture is possible in the peninsula has never yet been answered. Markets exist in the ports of Eastern Siberia, which are at present supplied with such articles as salt meat, butter, cloth, and hides from San Francisco. The main obstacle to agriculture is the excessively damp and constantly foggy climate. The sun seldom shines, and does not therefore give enough warmth for the growth of rye and wheat. The trade is almost wholly with California; and as there is little or no money there it is carricd on by a system of exchange, the natives offering their sable skins in return for such goods as they require. The articles conclude with an historical sketch of the peninsula down to the annexation of the Amoor region to Russia in consequence of the treaty with China of 1860 .

Tre latest news from Col. Przevalsky communicated to the Russian Geographical Society is dated January 20 and March 22. In the first of his letters the Russian traveller writes from Dynyouan-in, where he was staying at the residence of the Prince of Alashan. After leaving Urga on November 20, he reached this small town in Alashan on January 15, after a journey of 740 miles across the desert of Gobi. The cold in the neighbourloood of Urga was very intense, and the mercury was sometimes frozen ; in Alashan it was, on the cont ary, quite warm when there was no wind. M. Przevalsky proposed to leave Dynyouan-in the next day, and viô the Tchebsen temple reach Kuku-nor. He wrote his second letter from this place. Hc had crossed Southern Alashan and the Han-sou Mountains without difficulty. There he spent the month of February, principally in hunting and in zoological explorations, which yielded rich collcctions. On March 23 he was to leave Tchebs $n$ for Kuku-nor. The Chinese authorities did not hinder his advance, but refused to give him a guide for the sources of the Yellow River (Hoang-ho) ; the indefatigable traveller did not, however, attach any importance to this refusal, being sure of finding the sources of the Hoang-ho himself. When the Tsaidam was reached, M. Przevalsky proposed to establish his first station there, and to continue his journey with a few men and provisions. Ilis second station would be established at Ghast in Western Tsaidam. $\Lambda$ s to Thibet, he had decided to go to Lassa if the Thibetians did not oppose him. Otherwise he would explore only Northern Thibet as far as Lob-nor, endeavouring to penetrate as far south as possible.

ANother traveller wh w has been sent out by the Russian Geographical Society, M. Potanin, wrote on April I7 from Tientsin. The expedition had reached Chefoo on April 13 on board the corvette Skobsleff, and continued the journey on board a Chinese merchant ship. They proposed soon to reach Pekin, and there to obtain authorisation for the journey to Ordos and Han-sou viâ Utay or Kuku-Koto.

In a paper contributed to a recent issue of the Revue de l'Histoire des Religions, M. Léon de Rosny, the Japanese scholar, argues that one of the two chief chronological factors in the present Japanese race is the Aino. It has long been recognised that there was a certain intcrmingling of the original Japanese invaders with those whom they drove before them, and who now remain in parts of Yezo, the Kuriles, and Kamchatka ; but M. de Rosny thinks that the Aino element is an exceedingly large one, and permeates the whole race. His arguments are based on an examination of the commogony described in the earliest works. He finds here two separate and distinctly marked mythologies, one of a transparently aboriginal character. The Japanese of to-day is, he believes, a mixture of the conquering yellow and the conquered white races.

THE Berlin Geographical Socicty heard a lecture on October 4 from Herr Robert Flegel, who has just returned from making an exploration in the region of the Niger, as agent of the German A frican Society. Herr Flegel's exploration has occupied the last two years, in the course of which he explored all Adamawa and discovered the sources of the Binuë; but his effort to travel from the Binuë to the Congo ended in failure, owing to the feuds and violence of the intervening tribes. Herr Flegel carried away with him the conviction that the Binue is navigable for I yoo kilometres, and its chief affluents, as for instance the Taraba, for a distance of from fifty to sixty nautical miles during five or six months of the year. Herr Flegel is accompanied by two natives, who attended him on his travels, and who listened on bended knee and with crossed arms to the praise bestowed upon them by the President of the Geographical Society for their devotion to their master.

News has been received from the leader of the German expedition in South America, Dr. von den Steinen. The expedition had arrived at Aldea dos Bacairis, on the Rio Paranatinga, the ultimate point from which regular communication with the civilised world is possible. Their journey had been considerably delayed by untoward circumstances and difficulties. They left Cuyaba on May 26, and reached Rosario on June 2. There they stayed a few days to purchase provisions. On June I4 they reached the first Aldeamento of the Bacairis on the Rio Novo, a tributary of the Arino. There they remained a week, making anthropological and linguistic investigations. They continued their march on June 21 , and arrived at Aldea on the 28 th. On July 5 they were to cross the Paranatinga.

A Grographicat. Society is about to be founded in the Scottish capital; it is to be opened next month by Mr. H. M. Stanley.

\section{A GIGANTIC EARTHWORM}

$\mathrm{I}^{\mathrm{T}}$ is well known that earthworms exist in many parts of the world of enormous size compared to those with which we are familiar in this country.

Dr. Templeton mentions (see Procecdings of the Zoological Society, 1844, p. 89) large worms which are abundant after heavy showers in many parts of the island; this species, named by him Megascolex caruleus, is represented by a number of examples in the British Museum, some of which are certainly more than two fect long. In South America at least two distinct genera are to be found which attain to a very considerable size. Prof. Perrier, who is so well known as an authority upon the anatomy of the group, has given them the appropriate name of Anteus and Titanus. Dr. Horst of Leyden, also well known for his rescarches into the anatomy of earthworms, has published in the "Notes from the Leyden Museum" a description of two species belonging to another genus, Acanthodrilus, which measure three feet or so in length; they are natives of Western Africa. Australia and New Zealand are also inhabited by these gigantic creatures. Prof. Thomas, of Auckland, New Zealand, informs me that he has heard of a large earthworm two or three feet in length, which is to be found in the interior of the island, and one of similar size has lately been described from South Australia, by Prof. M'Coy, under the name of Meyascolides. There is, however, a still larger species which inhabits South Africa. Forty years ago Rapp described 
and figured an earthworm six feet two inches in length, which was obtained from the neighbourhood of Port Elizabeth, but since that time there does not appear to have been any further description of the animal. Being anxious to secure a specimen for dissection, I applied to the Rev. G. R. Fisk, who most kindly sent me a living one; it is the same species as that described by Rapp, but is not quite so large ; it measured between four and five feet in length, and about half an inch in diameter; these measurements are, however, rather under than over-stated; it is not easy to get an exact idea of the length of the animal, since it expands and contracts within such very wide limits. The general appearance is much like that of the common British species, the bristles being disposed in four series of pairs to each segment; this outward resemblance is not borne out by the internal structure, which is very different from that of Lumbricus or any other genus.

These monstrous worms appear to be fairly abundant in the neighbourhood of Port Elizabeth and other parts of the Cape Colony (see the Cafe Times for May 29, 1884), but are only rarely seen; they do not seem to move about at night like our B:itish worms; only heavy and prolonged rains drive them to the surface from their underyround burrows; on such occasions, as I am informed by a correspondent at Kleinpoort, which only take place a few times a year, the ground is often covered by hundreds of these creatures slowly crawling about in all directions ; they must present a most remarkable sight ; as a general rule they do not return into the earth after the rain has ceased, but remain above ground, and are shortly killed by the sun. The same gentleman states that the soil in which he has observed them is of a hard clayey nature, and retains a considerable amount of water, which is invariably brackish. This fact has some significance in connection with the geographical distribution of earthworms. It was formerly believed that earthworms and their eggs were killed by immersion in salt water, and consequently the presence of similar or closely-allied species in two regions now separated by the sea would be a strong indication of a previous land comnection, setting aside, of course, those cases evidently due to man's interference (i.e. the importation of earthworms from tropical countries among the roots of plants). The fact that this earthworm from the Cape, and presumably its eggs, are unaffected by brackish water, and still more the occurrence of another genus, Pontodrilus (cf. Perrier, Arch. de Zool. Exp., t. ix.), among decaying seaweed cast up by the sea, shows plainly that the greatest caution must be observed in drawing any such conclusions.

Zoological Gardens, N.W.

\section{F. E. BEDDARD}

\section{THE ACTION OF AMMONIA UPON SOME LEPIDOPTEROUS PIGMENTS}

TWO or three years back, some entomological friends induced me to kill all my insects with ammonia, instead of employing potassium cyanide, and I have never regretted the change I then made. Nearly the first species so treated was Melanargia salathea, and on opening the pill-boxes I was much surprised to find every one of them of a beautiful primrose-yellow colour. In a few moments the primrose-yellow had vanished and the insects were of their normal white again. Evidently this phenomenon was due to the volatile ammonia, so I held a specim: $n$ over the bottle, and instantly the primrose colour returned, only to disappear again with the departure of the pungent ammoniacal fumes. The reagent employed was a saturated aqueous solution of ammonia, and the black pigment of the wings remained unchanged throughout. Now here was something of great interest and well worth investigation, so I determined to follow it up, and since that time have never lost an opportunity for experiment or study. Many of my friends are now familiar with the results obtained, but as they appeared to be previously unknown to all those with whom I have communicated on the subject, I have thought it best to place them on record. They may be well known and authenticated, but to ascertain this a careful search through the vast mass of the chemical and microscopical literature both of this country and the Continent would be required, and for this my spare time is quite inadequate. I must therefore crave the indulgence of those who may be familiar with the facts herein recorded. Naturally, the first species selected for experiment was Melanargia galathea. As before, ammonia gave the primrose coloration. The next reagent employed was a solution of 1 otassium hydrate, in which pieces of the wing were placed, and they immediately turned yellow. Other alkalis, such as solutions of sodium hydrate and barium hydrate, were tried, and gave similar results, the only difference being that with the fixed alkalis the primrose coloration was permanent, whercas with ammonia it was necessarily fleeting.

As alkali turned the pigment yellow, acids I thought might prevent this, or even produce another colour. Accordingly the wings were treated with a great many acids, the chief being sulphuric, nitric, sulphurous, hydrochloric, phosphoric, and acetic. With all these, when used in excess of the alkali, the pigment was restored to its natural white colour. I also found, that whenever the liquid employed was exactly neutral to both red and blue litmus, the pigment remained unchanged, whilst the slightest addition of alkali produced the primrose-yellow, and when acid predominated the normal colour prevailed. Thus, we see, this pigment is a good test for alkalinity.

To enumerate all the species experimented upon would occupy too much space, so I will only give the most important. As some Continental species are mentioned, I have followed Staudinger's arrangement. Papilio machaon and other Papilios were unchanged, and the same may be said of the genus Thais. Parnassius apollo, $P$. delius, and $P$. mnemosyne turned a pale yellow. With such semi-transparent species a deeper coloration could not be expected, from the small amount of pigment present.

None of the species of Aporia, Pieris, or Anthocharis showed any alteration with ammonia, but Leucophasia sinapis and its vars. lathyri, \&c., exhibited a delicate primrose colour. Not a single species in Colias, Rhodocera, Thecla, or Polyommatus was changed; but the behaviour of the species of Lycana was extremely curious and somewhat unexpected. L. argiades, $L$. argiolats, minima (=alsus), semiargus (= acis), alcon, arion, and euphemus remained unaltered. L. batica, argyrotoxus (=eason), arous, opilete, orbitulus, tros, icarus (= alexis). eumedon, amanta, bellargus ( = adoni. $)$, meleager, jolas, and especially astrarihe ( = agestis), rorydon, and damon were beautifully suffused with primrose on the under side and cilia, wherever the white pigment occurs. It is difficult to say why some of the specics in this genus are unaffected, whilst others exhibit the most gorgeous colouring; but in the case of $L$. argiolus, at least, this may be accounted for. The pale bluish white of the under side is not the result of white pigment at all, but is due to reflected light from the almost pigmentless scales, in which a change could not be looked for. All the species which were examined in Nemeobius, Charaxes, Apatura, Limenitis, Visnessa, Melicar, and Arisynnis exhibited no change. In the Satyridæ, besides Melanargia, Enis allo is clearly suffused with primrose bencath. In Satyrus, S. circe and $S$. briseis have the white bands changed, but $S$. alcyone and $S$. semile are not affected. Evebia and Pararge are alike unchanged. Canonympha hero, C. arcania (and vars.), C. pamphilus, and typhon (=davus), have the cilia and under side deeply suffused with yellow. Of the Hesperidæ, Sptlothyrus alcee, Syrichthus alveolus, S. serra'ula, and malve (= alveolus), all have the whites changed to primrose, but Nisoniades, Hesperia, and Cartirocephalus are not affected.

With the Heterocera I have obtained but negative results, although the number of species operated upon are to be counted by hundreds. It would be unsafe to generalise with such scanty data to go upon, but a few remarks may be ventured. The white pigmentary deposits of Pieris and Melanargia, although to the eye the same, must have a very different chemical constitution, and at one time I thought the negative ammonia results would be a good character of the Picridie, in contradistinction to Melanaria, \&c. ; but facts would not support this speculation, for Leucoptha ia proved refractory, and the Satyridæe gave results by no means uniform. Many more experiments must be performed. Nature must be thoughtfully questioned agrain and again before we can possess a firm basis for speculation.

Hitherto changes of colour only have been dealt with, and few reagents employed, but by recent experiments on the solubility of the various pigments in different media, most interesting facts have been brought to light, which in the future I hope to communicate. What a wonderful and lovely sight is the under side of Vunessa utalanta! It has at least a dozen shades of colour, most exquisitely mingled. Some day these colours will be analysed and their constitution made known. The results herein recorded may then be of service.

24, Fleming Road, Lorrimore Square, S.E., August 16 